\title{
Diet and faecal flora in the newborn: casein and whey proteins
}

\author{
S E BALMER, P H SCOTT, ${ }^{*}$ AND B A WHARTON \\ Sorrento Maternity Hosptial and *Selly Oak Hospital, Birmingham
}

SUMMARY Despite the extensive modifications of cows' milk to make an infant formula resemble human breast milk, we showed in a previous study that the faecal flora of breast fed babies still differs substantially from that of formula fed babies. This paper describes the effects that differences in the distribution of whey proteins and caseins exert on the faecal flora. Faecal flora was examined in 33 babies receiving a whey formula, 29 babies receiving a casein formula, and 38 breast fed babies. Subsequently fewer babies in each group were studied at weeks 7,11 , and 15 . More whey fed babies were colonised with bifidobacteria at 14 days compared with the casein fed group, more casein fed babies were colonised with bacteroides (at 14 days), and more had a dominant growth of enterococci (at week 7). It seems therefore that during the first two months that the whey predominant formula induced a faecal flora generally closer to that of breast fed babies than did a casein formula.

In the preceeding paper it was shown that among breast fed babies bifidobacteria and staphylococci were the predominating organisms in the faeces whereas in bottle fed babies the predominating organisms were enterococci and Escherichia coli. ${ }^{1}$

Breast milk differs from a modern infant formula in many ways so that the dietary cause(s) for these microbiological differences is (are) not clear. This present investigation was therefore designed to determine the effects of protein quality (in particular the distribution of whey proteins and caseins) on the faecal flora. Few hospitals use a casein predominant formula but many mothers change their baby to a casein predominant one after some weeks and often following professional advice. The study therefore also provided an opportunity to determine the faecal flora of the substantial minority of babies who receive casein predominant formulas in the early weeks of life.

\section{Subjects and methods}

DIET AND BABIES (TABLES 1 AND 2)

On one postnatal ward between January and December 1987, babies, whose mothers had opted to bottle feed them, were allocated to receive either a whey predominant formula or a casein predominant one. The whey predominant formula used was Gold Cap SMA-known as S26 in some coun-
Table 1 Composition of the two test formulas and breast milk (per l)

\begin{tabular}{llll}
\hline & $\begin{array}{l}\text { Breast } \\
\text { milk }\end{array}$ & $\begin{array}{l}\text { Whey } \\
\text { formula } \\
\text { (Gold Cap) }\end{array}$ & $\begin{array}{l}\text { Casein } \\
\text { formula } \\
\text { (White Cap) }\end{array}$ \\
\hline $\begin{array}{l}\text { Protein g } \\
\text { (nitrogen } \times 6 \cdot 38)\end{array}$ & 11 & 15 & 15 \\
Total 'true' protein (\%) & $9(100)$ & $13(100)$ & $14(100)$ \\
$\quad$ Caseins & $2 \cdot 5(28)$ & $5 \cdot 2(40)$ & $11 \cdot 1(79)$ \\
Whey proteins & $6 \cdot 5(72)$ & $7 \cdot 8(60)$ & $2 \cdot 9(21)$ \\
$\quad \alpha$ Lactalbumin & $2 \cdot 6(29)$ & $1 \cdot 2(9)$ & $0 \cdot 6(4)$ \\
$\beta$ Lactoglobulin & - & $3 \cdot 4(26)$ & $1 \cdot 3(9)$ \\
$\quad$ Other whey & $3 \cdot 9(43)$ & $3 \cdot 2(25)$ & $1 \cdot 0(8)$ \\
Calcium (mg) & 350 & 450 & 560 \\
Phosphorus (mg) & 150 & 330 & 450 \\
Sodium (mg) & 150 & 150 & 200 \\
Potassium (mg) & 600 & 560 & 740 \\
Iron (mg) & 0.76 & $6 \cdot 7$ & $6 \cdot 7$ \\
\hline
\end{tabular}

Proteins for breast milk based on Hambraeus ${ }^{5}$ and for formulas they were calculated from manufacturers information and Jennes. ${ }^{6}$ Minerals for breast milk based on DHSS, $1977 .{ }^{7}$

tries (Wyeth). The casein predominant formula was White Cap SMA (Wyeth). The test formula offered on the postnatal ward was alternated at approximately monthly intervals - for example, all babies born during July were offered the whey formula, all those born during August were offered the casein formula, etc. Once allocated to a formula the babies 
Table 2 Data of babies taking part in the study

\begin{tabular}{lccc}
\hline & \multirow{2}{*}{$\begin{array}{c}\text { Breast } \\
\text { fed }\end{array}$} & \multicolumn{2}{l}{ Formula fed } \\
\cline { 3 - 4 } & & Whey & Casein \\
\hline $\begin{array}{l}\text { Day 14: } \\
\quad \text { No of babies }\end{array}$ & 38 & 33 & 29 \\
$\begin{array}{l}\text { Sex: } \\
\quad \text { Male }\end{array}$ & 20 & 15 & 12 \\
$\quad$ Female & 18 & 18 & 17 \\
$\begin{array}{l}\text { Race: } \\
\quad \text { White }\end{array}$ & 35 & 32 & 26 \\
$\quad \begin{array}{l}\text { Asian } \\
\text { Afro-Carribean }\end{array}$ & 0 & 0 & 1 \\
$\begin{array}{l}\text { Mean (SD) birth } \\
\quad \text { weight (g) }\end{array}$ & $3360(410)$ & $3520(490)$ & $3340(380)$ \\
$\begin{array}{l}\text { Week 7: } \\
\text { No of babies }\end{array}$ & 15 & 17 & 16 \\
$\begin{array}{l}\text { Week 11: } \\
\text { No of babies }\end{array}$ & 10 & 10 & 13 \\
$\begin{array}{l}\text { Week 15: } \\
\text { No of babies }\end{array}$ & 10 & 9 & 13 \\
\hline
\end{tabular}

remained on that formula (which was supplied free of charge) until they left the study. The formulas were supplied as 'ready to feed' liquid milk until the baby was 3 weeks old and thereafter the mothers were supplied with dried milk powder and they reconstituted the formula themselves. Breast fed babies were also studied and at the end of the study their mothers were given a voucher to purchase goods from a pharmacist's shop.

Compared with the casein formula, the whey formula contains more $\beta$ lactoglobulin, less casein, and (as casein is associated with both phosphorus and calcium) less phosphorus and calcium. The demineralisation process also results in lower electrolyte concentrations similar to those in breast milk. Both formulas contained added iron (table 1).

All babies were born at term (none less than 37 weeks' gestation) and all except one were born vaginally. The babies in the three groups were similar in size, etc (table 2).

\section{PROCEDURES}

Faeces were collected on day 14 and at week 7,11 , and 15. Anthropometry was recorded on day 1 . The methods used for microbiology and $\mathrm{pH}$ of faeces were exactly as described previously. ${ }^{1}$

STATISTICAL ANALYSIS

The results were analysed statistically using MannWhitney, Wilcoxon, $\chi^{2}$, and Student's $t$ test as appropriate.

ETHICAL APPROVAL

Approval for the study was obtained from the ethics committee of the South Birmingham Health Authority. The mothers of all babies taking part in the study gave written informed consent.

\section{IN VITRO STUDY}

The milk $\mathrm{pH}$ was measured using a standard $\mathrm{pH}$ meter (Radiometer PHM82) and the $\mathrm{pH}$ converted also to hydrogen ion concentration (nmol/l). Titration methods for the measurement of titratable acidity and buffering capacity were based on those of Harrison and Peat $^{2}$ and Bullen and Willis. ${ }^{3}$ Titratable acidity was defined as the volume $(\mathrm{ml})$ of $0.5 \mathrm{~mol} / \mathrm{l}$ sodium bicarbonate required to raise the $\mathrm{pH}$ of the milk from its initial value to $7 \cdot 40$, expressed per litre of milk. Buffering capacity was defined as the volume $(\mathrm{ml})$ of $0.1 \mathrm{~mol} / \mathrm{l}$ hydrochloric acid required to reduce the milk $\mathrm{pH}$ from its initial value to $5 \cdot 0$, expressed per litre of milk. Bicarbonate was measured by the method of Ibbott et al, ${ }^{4}$ and osmolality using a Roebling Automatik Osmometer, each expressed as $\mathrm{mmol} / \mathrm{l}$. Citrate was measured using a citric acid test kit produced by BCL London Ltd, expressed as $\mathrm{mmol} / \mathrm{l}$.

\section{Results}

For ease of reference the breast fed babies are often referred to as 'breast babies' or 'breast group' and similarly for the formula fed babies. All except one baby was delivered vaginally (see methods) so this variable does not have to be considered.

\section{MICROBIOLOGY}

Differences were seen mainly at day 14 and these results are presented in detail but results for follow up studies are also described. In the same way as in the preceding paper the results are shown in two ways: (1) counts of individual organisms examined in each baby, analysed statistically using the MannWhitney test and the presence or absence of an organism, analysed by the $\chi^{2}$ test (fig 1 , tables 3 and 4). (2) Patterns of dominance in individual babies (that is, a particular genus accounting for the highest count in the bacterial population examined); these were analaysed statistically by the $\chi^{2}$ test (fig 2).

\section{Day 14}

(1) Counts of individual organisms (fig 1)

Differences in the three dietary groups were seen only in the counts of staphylococci and bifidobacteria; no significant differences were seen with the other organisms.

Significant differences in the counts of organisms are shown in columns marked $a$ and $b$ :

(i) both groups of formula fed babies had lower 
Fig 1 Counts of individual organisms ( $\log _{I 0}$ colony forming units (CFU) per $g$ faeces) in the three dietary groups on day 14. a, Distribution of counts significantly different $(p<0.05)$ form breast fed babies (Mann-Whitney); $b$, distribution of counts significantly different $(p<0.05)$ from casein babies (Mann-Whitney); $x$, proportion of babies colonised significantly different $(p<0.05)$ from breast fed babies $\left(\chi^{2}\right.$ with Yates's correction); and $y$, proportion of babies colonised significantly different $(p<0.05)$ from casein babies ( $\chi^{2}$ with Yates's correction). $B=$ breast fed babies, $W=$ whey fed babies, and $C=$ casein fed babies.

counts of staphylococci than the breast fed babies $(\mathrm{p}<0.05)$;

(ii) the breast fed and whey fed babies had higher counts of bifidobacteria than the casein group $(p<0 \cdot 05)$.

More dietary differences were seen when the number of babies colonised, or not, were compared. Significant changes are shown in columns marked $\mathrm{x}$ and $\mathrm{y}$ : (i) fewer breast fed babies were colonised with other coliforms and enterococci than both of the formula fed groups $(\mathrm{p}<0.05)$;

(ii) more breast fed babies were colonised with staphylococci than both of the formula fed groups $(p<0 \cdot 05)$;

(iii) fewer casein babies were colonised with bifidobacteria compared with both breast and whey fed groups $(p<0 \cdot 05)$; 
Table 3 Comparison of faecal flora at week 7

\begin{tabular}{|c|c|c|c|}
\hline & \multirow{2}{*}{$\begin{array}{l}\text { Breast fed } \\
(n=15)\end{array}$} & \multicolumn{2}{|c|}{ Formula fed } \\
\hline & & $\begin{array}{l}\text { Whey } \\
(n=17)\end{array}$ & $\begin{array}{l}\text { Casein } \\
(n=16)\end{array}$ \\
\hline \multicolumn{4}{|l|}{ Escherichia coli: } \\
\hline No $(\%)$ of babies colonised & $9(60)$ & $15(88)$ & $12(75)$ \\
\hline Median count & 0.0001 & 0.5 & 0.04 \\
\hline Range of counts $\left(\times 10^{9} / \mathrm{g}\right)$ & $0-30$ & $0-20$ & $0-600$ \\
\hline \multicolumn{4}{|l|}{ Other coliforms: } \\
\hline No $(\%)$ of babies colonised & $7(47)$ & $2(13)$ & $6(38)$ \\
\hline Median count & 0 & 0 & 0 \\
\hline Range of counts $\left(\times 10^{9} / \mathrm{g}\right)$ & $0-100$ & $0-8$ & $0-0.7$ \\
\hline \multicolumn{4}{|l|}{ Bifidobacteria: } \\
\hline No $(\%)$ of babies colonised & $10(67)$ & $13(76)$ & $10(63)$ \\
\hline Median count & 0.8 & $2 \cdot 0$ & $0 \cdot 1$ \\
\hline Range of counts $\left(\times 10^{9} / \mathrm{g}\right)$ & $0-10$ & $0-90$ & $0-20$ \\
\hline \multicolumn{4}{|l|}{ Lactobacilli: } \\
\hline No $(\%)$ of babies colonised & $3(20)$ & $3(18)$ & $4(25)$ \\
\hline Median count & 0 & 0 & 0 \\
\hline Range of counts $\left(\times 10^{9} / \mathrm{g}\right)$ & $0-10$ & $0-0 \cdot 1$ & $0-10$ \\
\hline \multicolumn{4}{|l|}{ Staphylococci: } \\
\hline No $(\%)$ of babies colonised & $6(40)^{*}$ & $0^{*} \ddagger$ & $5(31) \ddagger$ \\
\hline Median count & 0 & 0 & 0 \\
\hline Range of counts $\left(\times 10^{9} / \mathrm{g}\right)$ & $0-0 \cdot 1$ & 0 & $0-3$ \\
\hline \multicolumn{4}{|l|}{ Enterococci: } \\
\hline No $(\%)$ of babies colonised & $8(53)^{*}+$ & $16(94)^{*}$ & $15(94) \dagger$ \\
\hline Median count & 0.006 & $1 \cdot 0$ & \\
\hline Range of counts $\left(\times 10^{9} / \mathrm{g}\right)$ & $0-40$ & $0-1$ & $0-1700$ \\
\hline \multicolumn{4}{|l|}{ Bacteroides: } \\
\hline No $(\%)$ of babies colonised & $5(33)$ & $12(71)$ & $7(44)$ \\
\hline Median count & 0 & & 0 \\
\hline Range of counts $\left(\times 10^{9} / \mathrm{g}\right)$ & $0-40$ & $0-100$ & $0-30$ \\
\hline \multicolumn{4}{|l|}{ Clostridia: } \\
\hline No $(\%)$ of babies colonised & $8(53)$ & $9(53)$ & $14(88)$ \\
\hline Median count & 0 & 0.00001 & 0.01 \\
\hline Range of counts $\left(\times 10^{9} / g\right)$ & $0-1$ & $0-1$ & $0-0.3$ \\
\hline
\end{tabular}

Significant differences by $\chi^{2}$ test: *differences between babies fed breast milk and whey formula; †differences between babies fed breast milk and casein formula; and $\ddagger$ differences between babies fed casein and whey formulas.

(iv) more casein babies were colonised with bacteroides compared with breast fed babies $(\mathrm{p}<0.05)$.

\section{(2) Patterns of dominance (fig 2)}

Dominance of bifidobacteria occurred in more breast fed than formula fed babies $(p<0.05)$. Although not significant more whey babies $(15 \%)$ had bifidobacteria as the dominant organisms compared with the casein group (7\%).

Follow up study-weeks 7, 11, and 15 (tables 3 and 4) There were very few significant changes and dietary differences in the faecal flora examined in subsequent specimens collected during the follow up study.

(1) Counts of individual organisms

There was no difference in the counts of individual organisms between the breast fed and either of the formula fed groups. There were a few dietary differences in the presence or absence of organisms:

(i) more breast fed babies (40\%) and casein babies $(31 \%)$ were colonised with staphylococci at week 7 than whey babies $(0 \%)(\mathrm{p}<0.05, \mathrm{p}<0.05)$;

(ii) fewer breast fed babies $(53 \%)$ were colonised with enterococci at week 7 than either of the formula fed groups $(94 \%)(p<0.05)$;

(iii) more breast fed babies $(60 \%)$ and whey fed babies $(56 \%)$ were colonised with other coliforms at 15 weeks than casein babies $(11 \%)(p<0.04, p<0.06$

(2) Patterns of dominance (fig 2)

Significant dietary differences in the dominance patterns were seen only at week 7 . Apparent differences seen at week 15 (see fig 2) were not significant. More casein babies $(44 \%)$ had a dominance of enterococci than breast babies $(7 \%)$ at week 7 $(\mathrm{p}<0.05)$. 
Table 4 Comparison of faecal flora at weeks 11 and 15

\begin{tabular}{|c|c|c|c|}
\hline \multirow[b]{2}{*}{ Week 11} & \multirow{2}{*}{$\begin{array}{l}\text { Breast fed } \\
(n=10)\end{array}$} & \multicolumn{2}{|c|}{ Formula fed } \\
\hline & & $\begin{array}{l}\text { Whey } \\
(n=10)\end{array}$ & $\begin{array}{l}\text { Casein } \\
(n=13)\end{array}$ \\
\hline \multicolumn{4}{|l|}{ Escherichia coli: } \\
\hline No $(\%)$ of babies colonised & $7(70)$ & $9(90)$ & $11(85)$ \\
\hline Median count & 0.06 & 1.05 & \\
\hline Range of counts $\left(\times 10^{9} / \mathrm{g}\right)$ & $0-10$ & $0-30$ & $0-20$ \\
\hline \multicolumn{4}{|l|}{ Other coliforms: } \\
\hline No $(\%)$ of babies colonised & $6(60)$ & $4(40)$ & $6(46)$ \\
\hline Median count & $0 \cdot 25$ & 0 & 0 \\
\hline Range of counts $\left(\times 10^{9} / \mathrm{g}\right)$ & $0-7$ & $0-1$ & $0-10$ \\
\hline \multicolumn{4}{|l|}{ Bifidobacteria: } \\
\hline No $(\%)$ of babies colonised & $7(70)$ & $9(90)$ & $9(69)$ \\
\hline Median count & 0.5 & 1.0 & $1 \cdot 0$ \\
\hline Range of counts $\left(\times 10^{9} / \mathrm{g}\right)$ & $0-50$ & $0-30$ & $0-20$ \\
\hline \multicolumn{4}{|l|}{ Lactobacilli: } \\
\hline No $(\%)$ of babies colonised & $2(20)$ & $2(20)$ & $2(15)$ \\
\hline Median count & 0 & 0 & 0 \\
\hline Range of counts $\left(\times 10^{9} / \mathrm{g}\right)$ & $0-0 \cdot 2$ & $0-0 \cdot 04$ & $0-0 \cdot 3$ \\
\hline \multicolumn{4}{|l|}{ Staphylococci: } \\
\hline No $(\%)$ of babies colonised & $3(30)$ & $2(20)$ & $2(15)$ \\
\hline Median count & 0 & 0 & 0 \\
\hline Range of counts $\left(\times 10^{4} / \mathrm{g}\right)$ & $0-01$ & $0-5$ & $0-1$ \\
\hline \multicolumn{4}{|l|}{ Enterococci: } \\
\hline No $(\%)$ of babies colonised & $9(90)$ & $9(90)$ & $11(85)$ \\
\hline Median count & $0 \cdot 65$ & $0 \cdot 15$ & 1.0 \\
\hline Range of counts $\left(\times 10^{4} / g\right)$ & $0-6$ & $0-20$ & $0-20$ \\
\hline \multicolumn{4}{|l|}{ Bacteroides: } \\
\hline No $(\%)$ of babies colonised & $3(30)$ & $7(70)$ & $5(38)$ \\
\hline Median count & 0 & $0 \cdot 22$ & 0 \\
\hline Range of counts $\left(\times 10^{4} / \mathrm{g}\right)$ & $0-9$ & $0-20$ & $0-30$ \\
\hline \multicolumn{4}{|l|}{ Clostridia: } \\
\hline No $(\%)$ of babies colonised & $6(60)$ & $7(70)$ & $8(62)$ \\
\hline Median count & 0.000005 & $0 \cdot 00055$ & 0.01 \\
\hline Range of counts $\left(\times 10^{9} / \mathrm{g}\right)$ & $0-9$ & $0-1$ & $0-0 \cdot 1$ \\
\hline Week 15 & $(n=10)$ & $(n=9)$ & $(n=13)$ \\
\hline \multicolumn{4}{|l|}{ Escherichia coli: } \\
\hline No $(\%)$ of babies colonised & $9(90)$ & $4(44)$ & $13(100)$ \\
\hline Median count & 0.51 & 0 & 1 \\
\hline Range of counts $\left(\times 10^{4} / \mathrm{g}\right)$ & $0-6$ & $0-40$ & $0-30$ \\
\hline \multicolumn{4}{|l|}{ Other coliforms: } \\
\hline No $(\%)$ of babies colonised & $6(60)$ & $5(56)^{*}$ & $2(11)^{*}$ \\
\hline Median count & 0.01 & $0 \cdot 0001$ & 0 \\
\hline Range of counts $\left(\times 10^{y} / \mathrm{g}\right)$ & $0-10$ & $0-10$ & $0-0 \cdot 1$ \\
\hline \multicolumn{4}{|l|}{ Bifidobacteria: } \\
\hline No $(\%)$ of babies colonised & $8(80)$ & $5(56)$ & $8(62)$ \\
\hline Median count & 0.05 & 0.004 & $0 \cdot 9$ \\
\hline Range of counts $\left(\times 10^{9} / \mathrm{g}\right)$ & $0-700$ & $0-10$ & $0-20$ \\
\hline Lactobacilli: & & & \\
\hline No $(\%)$ of babies colonised & $2(20)$ & $1(11)$ & $3(23)$ \\
\hline Median count & 0 & 0 & 0 \\
\hline Range of counts $\left(\times 10^{\%} / \mathrm{g}\right)$ & $0-1$ & $0-(0 \cdot 04$ & $0-1$ \\
\hline Staphylococci: & & & \\
\hline No $(\%)$ of babies colonised & $4(40)$ & $2(22)$ & $3(23)$ \\
\hline Median count & 0 & 0 & 0 \\
\hline Range of counts $\left(\times 10^{y} / \mathrm{g}\right)$ & $0-1$ & $0-0 \cdot 02$ & $0-0 \cdot 2$ \\
\hline Enterococci: & & & \\
\hline No $(\%)$ of babies colonised & $10(100)$ & $8(89)$ & $13(100)$ \\
\hline Median count & $1 \cdot 5$ & 1 & 2 \\
\hline Range of counts $\left(\times 10^{9} / \mathrm{g}\right)$ & $0-30$ & $0-10$ & $0-10$ \\
\hline Bacteroides: & & & \\
\hline No $(\%)$ of babies colonised & $4(40)$ & $3(33)$ & $9(69)$ \\
\hline Median count & 0 & 0 & 0.2 \\
\hline Range of counts $\left(\times 10^{9} / \mathrm{g}\right)$ & $0-80$ & $0-20$ & $0-20$ \\
\hline Clostridia: & & & \\
\hline No $(\%)$ of babies colonised & 10) $(100)$ & $5(55)$ & $10(77)$ \\
\hline Median count & $0 \cdot 055$ & 0.00001 & 0.01 \\
\hline Range of counts $\left(\times 10^{9} / \mathrm{g}\right)$ & $0-100$ & $0-20$ & $0-0.5$ \\
\hline
\end{tabular}

Significant differences by $\chi^{2}$ test $^{*}:{ }^{*}$ differences between babies fed casein and whey formulas. 
Diet and faecal flora in the newborn: casein and whey proteins 1683

Table 5 Mean (SD) pH of faeces

\begin{tabular}{|c|c|c|c|}
\hline & \multirow[t]{2}{*}{ Breast fed } & \multicolumn{2}{|l|}{ Formula fed } \\
\hline & & Whey & Casein \\
\hline \multicolumn{4}{|l|}{ Day 14: } \\
\hline No of babies & & 33 & 29 \\
\hline $\mathrm{pH}$ & $6.18(0.67)^{*} \dagger$ & $6.87(0.71)^{*}$ & $7 \cdot 12(0.58) \dagger$ \\
\hline \multicolumn{4}{|l|}{ Week 7: } \\
\hline No of babies & & 17 & 16 \\
\hline pH & $6.92(1 \cdot 15)$ & $7 \cdot 11(0 \cdot 78)$ & $7.44(0.54)$ \\
\hline \multicolumn{4}{|l|}{ Week 11: } \\
\hline No of babies & 10 & 10 & 13 \\
\hline pH & $6.99(0.90)$ & $7 \cdot 23(0 \cdot 70)$ & $7.63(0.73)$ \\
\hline \multicolumn{4}{|l|}{ Week 15: } \\
\hline No of babies & 10 & 9 & 13 \\
\hline $\mathrm{pH}$ & $6.89(1.08)$ & $7.22(0.84)$ & $7.26(0.69)$ \\
\hline
\end{tabular}

Significant differences using $t$ test: *difference between babies fed breast milk and whey formula $(\mathrm{p}<0.01)$ and †difference between babies fed breast milk and casein formula $(p<0.001)$.

\section{Changes with time}

Changes in time were studied in each baby by analysing the results with Wilcoxon test but no significant changes in the faecal microflora were found on any of the diets throughout the 15 weeks of the study.

FAECAL PH (TABLE 5)

The breast babies had consistently more acidic faeces than the formula babies, although this was only significant on day 14 . There was a tendency for the breast fed babies faeces to become less acidic throughout the period of the study but the change from day 14 was only significant at week 11 $(p=0.04)$. There was no change of the $\mathrm{pH}$ of the faeces of the formula fed babies and there was no difference in the $\mathrm{pH}$ between the whey and the casein fed babies.
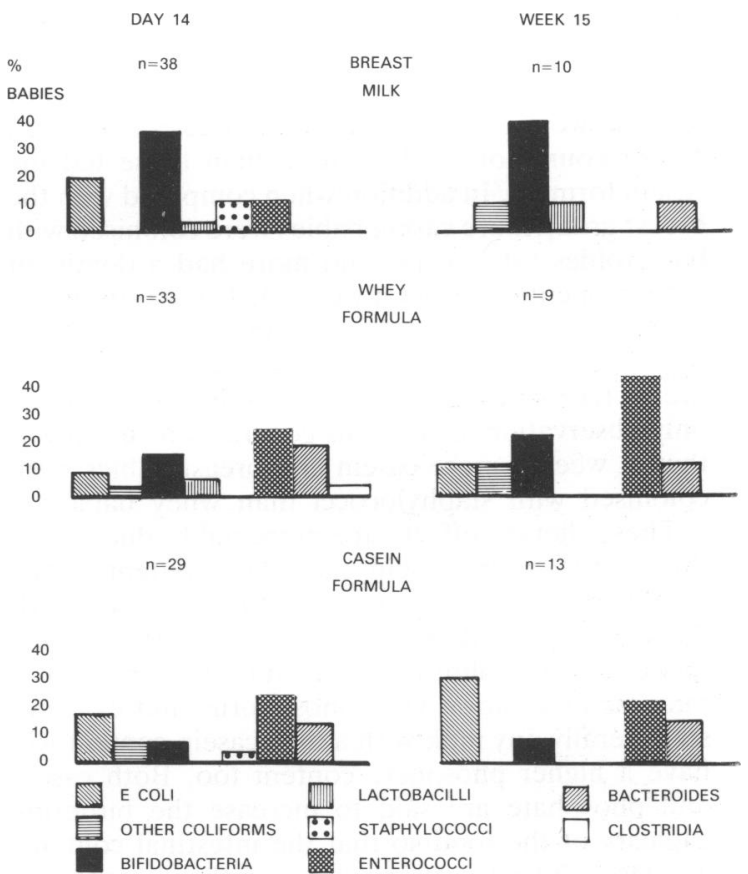

Fig 2 Percentage of babies in whose faeces organisms were dominant at day 14 and week 15.

IN VITRO STUDY (TABLE 6)

The casein formulas compared with the whey ones had higher values for hydrogen ion and titratable acidity (and to this extent were closer to breast milk) and had higher values for buffering capacity and citrate (and to this extent were further away from breast milk). The differences were more noticeable in the powder formulas than the liquid ones with the exception of bicarbonate.

Table 6 Acid base properties of the milks used in the study

\begin{tabular}{|c|c|c|c|c|c|c|}
\hline & \multirow{2}{*}{$\begin{array}{l}\text { Cows' } \\
\text { milk }\end{array}$} & \multirow{2}{*}{$\begin{array}{l}\text { Breast } \\
\text { milk* }^{*}\end{array}$} & \multicolumn{2}{|c|}{ Whey formula } & \multicolumn{2}{|c|}{ Casein formula } \\
\hline & & & Liquid & Powder & Liquid & Powder \\
\hline Milk pH & $6 \cdot 68$ & $6 \cdot 59$ & $6 \cdot 73$ & $7 \cdot 05$ & $6 \cdot 69$ & $6 \cdot 75$ \\
\hline Hydrogen ion concentration $(\mathrm{nmol} / \mathrm{l})$ & 210 & 257 & 186 & 89 & 204 & 178 \\
\hline Titratable acidity $\dagger$ & 208 & 122 & 110 & 50 & 147 & 133 \\
\hline Buffering capacity $\ddagger$ & 36 & 12 & 15 & 17 & 16 & 20 \\
\hline Bicarbonate $(\mathrm{nmol} / \mathrm{l})$ & $5 \cdot 4$ & $0 \cdot 5$ & $2 \cdot 5$ & $2 \cdot 0$ & $1 \cdot 0$ & $2 \cdot 3$ \\
\hline Citrate $(\mathrm{nmol} / \mathrm{l})$ & $12 \cdot 4$ & $2 \cdot 8$ & $2 \cdot 9$ & $4 \cdot 3$ & $4 \cdot 5$ & $5 \cdot 1$ \\
\hline Osmolality (nmol/l) & 282 & 290 & 307 & 332 & 307 & 326 \\
\hline
\end{tabular}

${ }^{*}$ Breast milk sample from mother who had been lactating for six weeks.

† Volume $(\mathrm{ml})$ of $0.5 \mathrm{~mol} / \mathrm{l}$ sodium bicarbonate required to raise the $\mathrm{pH}$ of the milk from its initial value to 7.40 (expressed per litre of milk). $\ddagger$ Volume (ml) of $0 \cdot 1 \mathrm{~mol} / 1$ hydrochloric acid required to reduce the milk pH from its initial value to $5 \cdot 0$ (expressed per litre of milk). 


\section{Discussion}

At 2 weeks of age more babies receiving the whey formula were colonised with bifidobacteria and had higher counts of bifidobacteria than those fed the casein formula. In addition when compared with the breast group more casein babies were colonised with bacteroides (at day 14) and more had a dominant growth of enterococci (at week 7). These differences were not seen in the whey groups. It seems that a whey formula induces a faecal flora closer to that of breast fed babies than does a casein formula. The only observation against this general conclusion was that at week 7 more casein and breast babies were colonised with staphylococci than whey babies.

These dietary effects are presumably due to the differences in the casein and whey content of the two formulas. The casein content is also associated, however, with other differences, in particular the amount of phosphorus and calcium. Casein forms a micellar association with phosphorus and calcium, so generally any milk with a high casein content will have a higher phosphate content too. Both casein and phosphate are said to increase the buffering capacity of the food so that the intestinal contents are less acidic favouring the growth of organisms other than bifidobacteria. ${ }^{3}$ Certainly the phosphorus concentration was shown to have an effect upon microbial activity in an in vitro study using a continuous culture technique with the rumen contents of sheep. ${ }^{8}$

The results of our in vitro study indicated that the $\mathrm{pH}$ and the titrable acidity of the formula bore little relationship to that of the faeces. We found it difficult to relate the observed in vivo microbiological differences in the babies to the in vitro acid base differences in the formulas (table 6). We cannot confirm therefore that the differences in the microbiological effects of whey and casein are mediated via an acid base mechanism.

Casein apart, the whey proteins of breast milk are very different from the whey proteins of cows' milk. In particular the whey formula contained much more $\beta$ lactoglobulin and the whey proteins contain little lactoferrin. In vitro experiments suggest that lactoferrin has a specific effect on gut flora and this is examined in more detail in the next paper.

This study was partly funded by Wyeth Laboratories, PO Box 8299, Philadelphia, USA. We are grateful to Mrs C Boyle and Mrs N Burton for the collection of specimens.

\section{References}

' Balmer SE, Wharton BA. Diet and faecal flora in the newborn: breast milk and infant formula. Arch Dis Child 1989;64:1672-7.

2 Harrison C, Peat G. Significance of milk pH in newborn infants. Br Med J 1972;iv:515-8.

${ }^{3}$ Bullen CL, Willis AT. Resistance of the breast fed infant to gastroenteritis. $\mathrm{Br}$ Med $J$ 1971;iii:338-43.

4 Ibbott AF, Laganga TS, Gin JB, Inkpen JA. Blood, pH, $\mathrm{CO}_{2}$ and $\mathrm{O}_{2}$. In: Henry $\mathrm{RJ}$, Cannon DC, Winkelman JW, eds. Clinical chemistry: principles and technics. London: Harper and Row, 1974:786-8.

5 Hambraeus L. Human milk composition. Nutrition Abstracts Review A 1984;54:219-36.

6 Jennes R, Sloan RE. The composition of milks of various species: a review. Dairy Science Abstracts 1970;32:599-612.

7 Department of Health and Social Security. Composition of mature human milk. (Report 12.) London: HMSO, 1977.

${ }^{8}$ Komisarczuk S, Merry RJ, McAllan AB. Effects of phosphorus on rumen microbial fermentation and synthesis determined using a continuous culture technique. Br J Nutr 1987;57:279-90.

Correspondence and requests for reprints to Dr SE Balmer, Milk Bank, Sorrento Maternity Hosptal, 15 Wake Green Road, Birmingham B13 9HE.

Accepted 17 April 1989 